\title{
Hayek Upside-Down: On the Democratic Effects of Transnational Lists
}

\author{
Marija Bartl*
}

\section{A. Introduction}

The breadth of EU influence, combined with the heftiness of its governing structures, may be felt to be unproblematic in times of relative prosperity. In times of economic, environmental, or social malaise, however, this ceases to be the case. Not only is the EU partially responsible for many of the challenges Europeans face, but it has also failed to respond in areas where it clearly has a "comparative advantage" over its member states. This constellation reinforces a growing sense-permeating the political imaginaries on all sides of the political spectrumthat the EU is an unresponsive and non-transformable Moloch.

The non-responsiveness of the EU can be attributed to two main causes. On the one hand, substantively, given the constitutionally limited breadth of issues open to EU political decisionmaking, the EU cannot greatly affect many issues that EU citizens care about-for example, questions of solidarity and taxation. On the other hand, institutionally - and this is where this contribution aims to intervene-the EU has never grown into a democratic political community. EU member states have jealously guarded their claims to being the sole "proper" democracies, not even allowing the slightest concession which might lead to the development of the European public sphere. The rejection of EU lists for the seats in the European Parliament to be vacated by the $\mathrm{UK}^{1}$ - were Brexit to go ahead - is the most flagrant recent example.

These substantive and institutional barriers have made it impossible to develop EU-wide political programs and movements, with rare exceptions, ${ }^{2}$ and thus also alternative, bottom up visions of Europe. Foremost, I will argue that these holdups have inhibited the sense of democratic governability of Europe: A perception that Europeans can collectively — through political agency—determine their destiny.

A turn towards national institutions may therefore seem to be the only way out. Is there a different way?

\section{B. Why We Need to Move Beyond the EU as a "Project"}

In a widely-circulated program for Europe, the French president, Emmanuel Macron, affirms that "Europe is not just an economic market. It is a project." ${ }^{3}$ In so doing, he hopes to move the European Union beyond its current impasse-turning it into a Europe that protects, rather than

${ }^{*}$ Marija Bartl is an Associate Professor of Law at the University of Amsterdam. The second section of this Article draws on the op-ed published by the author in SOCIAL EUROPE: From Europe-as-a-project to Real Political Community, published on April 24th, 2019. The op-ed is available at: https://www.socialeurope.eu/from-europe-as-project.

${ }^{1}$ Simon Usherwood, What Happens to the UK's Seats in the European Parliament After Brexit?, THE UK IN A CHANGING EUR. (May 1, 2018), https://ukandeu.ac.uk/what-happens-to-the-uks-seats-in-the-european-parliament-after-brexit/.

${ }^{2}$ See, e.g., DiEM25, WIKIPEDIA, https://nl.wikipedia.org/wiki/DiEM25 (last visited Oct. 20, 2019).

${ }^{3}$ Emmanuel Macron, Dear Europe, Brexit Is a Lesson for All of Us: It's Time for Renewal, THE GUARDIAN (Mar. 4, 2019, 2:17 PM), https://www.theguardian.com/commentisfree/2019/mar/04/europe-brexit-uk. 
threatens; a Europe of progress for all its citizens. Yet this language reveals something deeply problematic about our imagery of Europe, which paradoxically stands in the way of the Union realizing Macron's aspirations.

Seeing the EU as a "project" echoes a longstanding preoccupation with Europe's progressive construction and supposed destination-in other words, its directionality. This is omnipresent in its constitutional documents referencing an "ever closer union,"4 its legislation that is relentlessly oriented towards building the internal market, the case law of its courts applying a teleological ${ }^{5}$ interpretation of EU law, and its underlying political processes using "more or less Europe"6 as the central framing category of political discussion.

It is this preoccupation with directionality that so strikingly sets the EU apart from its member states. We do not query the "destination" of Italy or Poland-unless we have some cataclysmic event in mind. These political communities just are. Whatever direction they take-and whatever we think of that-is fundamentally a matter of politics.

Presenting the EU as a project frames it as something unfinished that needs further construction. It becomes an entity that is about policies rather than politics, ${ }^{7}$ where the greater preoccupation is with moving forward rather than reflection about the goals or direction. Moreover, a project is then also best left to its architects - that is, the EU member states and transnational elites. Opening it to unpredictable interventions through democratic politics may lead to the failure of the intuited, if not fully envisaged, construction plan.

The fact that we are as preoccupied with the EU's directionality today as we were at its establishment six decades ago is something that should worry us. "Well," one might ask, "shouldn't we know where and what we are by now?"

Yet, this abiding concern with directionality should not come as a surprise. Europe has emerged as a "functional" integration project, oriented toward a particular goal-building a common market - even though it was vested, at least in the first decades, with many other, albeit underlying, plans and hopes-from ensuring lasting peace to building a political union.

And, undoubtedly, the project of the internal market has progressed immensely. Not only is the internal market much more of a reality today than sixty, twenty, or even just ten years ago, but economic integration has also "spilled over" into many fields: Human rights, health, education, collective bargaining, and so on.

Yet, this success has not been universally celebrated. Many commentators have noted that "spillover" has in recent decades acquired a particularly neoliberal cast, given that the EU has used competitiveness, privatization, "liberalization" of public services, or the "flexibilization" of labor markets as the main vehicles of integration.

Be it as it may, despite this great expansion, the EU did not make a qualitative leap so as to turn from an integration project-economic or otherwise-into a democratic political communitywhere the question of direction or destination becomes a matter of democratic politics. On all three levels-democratic, political, and community-the EU seems wanting.

\section{Democratic}

The EU was democratically flawed from its establishment and it has remained so ${ }^{9}$ despite all the Treaty amendments pushing changes to its institutional structures. In particular, none of

\footnotetext{
${ }^{4}$ Ever Closer UnION, https://rometreaties.eu/ (last visited Oct. 20, 2019).

${ }^{5}$ Miguel P. Maduro, Interpreting European Law: Judicial Adjudication in a Context of Constitutional Pluralism, 1(2) Eur. J. Legal Stud. 137 (2007).

${ }^{6}$ White Paper on the Future of Europe, Eur. Commission (Mar. 1, 2017).

${ }^{7}$ Vivien Schmidt, Democracy in Europe: The EU and National Polities (2006).

${ }^{8}$ Phillippe C. Shmitter, Ernst B. Haas and the Legacy of Neofunctionalism, 12 J. Eur. Pub. Pol'y 255 (2005).

${ }^{9}$ Andreas Follesdal \& Simon Hix, Why There is a Democratic Deficit in the EU: A Response to Majone and Moravcsik, 44(3) J. Common Mkt. Stud. 533 (2006).
} 
the changes pursued the creation of institutional conditions that stand any chance to stimulate exchange on European issues across Europe. The most notable example is a consistent refusal to introduce "transnational lists" for the elections to the EU parliament. These lists are addressed to a Europe-wide constituency, giving European citizens a chance to vote for common candidates on the basis of Europe-wide political programs. Instead, and despite all the criticism, European elections are still based on national lists and national programs-having little to no engagement with EU policies.

\section{Political}

The aforementioned institutional constraints have made it extremely difficult not only to develop EU-wide political programs and movements, but also to create a credible vehicle to pursue change in Europe by democratic-rather than technocratic-means. With the growing powers of the EU, this dissociation of democratic process(es) from having an actual impact on political change has undermined one of the basic social imageries of modernitythat of collective self-determination-with the resulting political backlash. ${ }^{10}$

\section{Community}

EU economic integration has certainly not been at much risk of tipping over into solidarity, both among the EU member states or within their confines. Yet, without solidarity ${ }^{11}$ and risk sharing, there is no political community, or, for that matter, any other kind of community. Some notable examples of this dissociation include: A monetary union without a fiscal union, a limited recognition of the developmental needs of EU periphery, fiscal deficit rules, and limited EU competences in taxation. Questions of EU-wide solidarity and risk-sharing have also remained anathema in political discourses across national public spheres. The lack of a shared European public sphere made it difficult not only to develop a sense of belonging between EU citizens that would ground solidarity, but also prevented the emergence of pan-European political programs that would have to tackle the questions of distributive justice across the EU, and which would have to be discussed and defended as such at both European and national levels.

\section{On the Limits of "Sui Generis" Thesis}

In response to previous mentioned critiques of EU design, one of the fashionable responses was to suggest that the EU is an entity sui generis, which should not be judged on the basis of such outdated, state-inflected models of government, or governance if one prefers. Yet, if the populist turn has shown anything, it is that this excuse is past its prime.

The EU is undoubtedly a powerful weapon against many threats: It is better placed than its member states to respond to the concerns of globalization, to take decisive action against climate change, or to formulate a response to migration and refugees crises. In many ways, the EU is the most effective answer to the concerns of those who vote both right and left today. Yet, the EU has taken only limited action in any of these fields, giving strong arguments to its critics from both ends of the political spectrum.

It goes beyond the scope of this Article to discuss the reasons for these failures. Suffice it to say that the lion's share of responsibility is borne by the EU's technocratic structures, which became the vehicles for implementing the economic orthodoxy of the day, while also steering the EU into a

\footnotetext{
${ }^{10}$ This problem has another layer, that is, the emptying of national politics in the wake of "third way" consensus. See generally Chantal Mouffe, ON the Political (2005).

${ }^{11}$ Stefan Wallaschek, Without Solidarity, Democracy is Lost, Soc. EuR. (Mar. 26, 2019), https://www.socialeurope.eu/ without-solidarity-democracy-lost.
} 
non-democratically vindicated future in a manner that is often blind to the daily reality of various unprivileged groups in EU society. The EU member states carry another share of responsibility for pursuing their short-sighted national and personal interests, while failing to take seriously the expansion of EU powers by providing institutional and substantive structures that can legitimize the EU's growing impact.

More prospectively, if we are to legitimize EU power and, even more importantly perhaps, enable EU citizens to pursue democratic reform and change through the EU-rather than shove them to national institutions as the only democratic alternative-we first and foremost need to create conditions for the pan-European political space: a European public sphere so to say, where European democratic politics would stand in somewhat more direct relation to EU goals and policies.

Moreover, the question of what should be open to EU political discussion, and what should not, should be left to the political debate itself. In particular, the issues of greatest political concern, such as taxation or (re)distribution, seem to be particularly bad candidates for a-priori exclusion, in particular from an entity that is concerned with market making and structuring. Even if a political exchange on such an important political question may be divisive at the outset, any serious concerns with the capacity of European citizens to engage constructively in such debates bear little credibility in a constellation where the elites have designed their own project of EU's insolidarity - thus contributing to the current political backlash. EU citizens could hardly do any worse.

\section{Hayek Upside-Down: On Transnational Lists and EU Democracy}

While many political programs for the transformation of Europe have been put forth, and not without merit, there are few single measures that can bring about such a political transformation as transnational lists: pushing to the center the need to articulate pan-European party positions on uncomfortable questions related to inter- and intra-state solidarity, distribution, climate, or taxation, with transformative potential for both European and national politics. Given that democratization of Europe has been one of the few relatively broadly shared objectives in the European Parliament, for all kinds of reasons, it is particularly disappointing that it was the European Parliament itself that has failed to make use of the opportunity to re-apportion some seventy UK seats to be vacated ${ }^{12}$ were Brexit to occur.

Several concerns ${ }^{13}$ have been put forth in the European Parliament against these lists: Ranging from a straightforward claim that the EU is not a federation and thus such lists are not necessaryraised by the European People's Party, to the fact that we should instead save several million euros by not filling the UK seats-raised by both the European People's Party and the European Union Left/Nordic Green Left. The equality between different members of the European Parliamentthose selected from transnational lists and those selected from national lists-ultimately seems to have been a deal-breaker: Those selected from the national lists felt that they would be seen as "lesser" members of the European Parliament. ${ }^{14}$

From a democratic standpoint, the concern that resonated most broadly was the weakening of the link between these Euro-politicians and their eventual European constituency. Several European People's Party members of the European Parliament have been concerned that the emergence of these "super-politicians," who can't have a real link to the entire European constituency, would undermine European democracy.

\footnotetext{
${ }^{12}$ Usherwood, supra note 1.

${ }^{13}$ Cecil Barbiere, European Parliament Votes Against Transnational Lists, EuRACTIV (Feb. 7, 2018), https://www.euractiv. com/section/elections/news/ep-votes-against-transnational-lists/ (last updated Dec. 5, 2018).

${ }^{14}$ Alberto Alemanno, Why Transnational Lists Matter for EU Democracy, Euractiv (Feb. 7, 2018), https://www.euractiv. com/section/elections/opinion/why-transnational-lists-matter-for-eu-democracy/.
} 
One response to this conception of European democracy was raised by Alberto Alemanno, ${ }^{15}$ who suggested that the members of the European Parliament are here to represent EU citizens-rather than their national or local constituencies-and thus that they should make efforts to connect with a broader base. Others have suggested that many of the smaller parties, in most national contexts, do not have resources to create such direct links to voters in the districts where they are elected. Yet, that does not make them unrepresentative. Indeed, in 2019, we can imagine that connection does not necessarily have to take place through face-to-face encounters, however appealing we may find it.

In addition to these arguments, I would like to argue that at the most fundamental level, the "representativeness" hinges much more on the: (a) visibility of political programs, and (b) the capacity to bring about change through democratic process, rather than any tight personal contact with the base. Ultimately, if we are to rank what gives one a vital sense of living in a democracy, it is not the occasional meeting with a local political representative, but instead it is the chance to choose a political program that one finds appealing, and changing the course of public affairs if such a program commands a sufficient majority.

Transnational lists have the benefit of having to produce two things. First, EU wide political programs, which would have to be discussed and defended in national communities, would transform national political landscapes in terms of both the framing of issues on the political agenda and the appropriate level of intervention. Second, if such programs were to mobilize considerable support among EU citizens, not only would they produce a genuinely European parliament, but also exert pressure on technocratic institutions to implement such political programs. Let me unpack this.

Today, the members of the main EU parliamentary groupings-EPP, S\&D, ALDE, GUE-NGL, NI, etc., run for the parliamentary elections on the basis of national programs that address EU issues only tangentially and in whatever form the party deems fit. This allows the participating parties to effectively avoid addressing important political questions in a manner that would compel them to account for important cleavages in European politics, be it small states vs. big states, south vs. north, west vs. east, etc. To put it differently, German and Greek Members of the European People's Party (ie. Christian Democratic Union in Germany, and New Democracy in Greece) never really had to come up with the joint position with regard to austerity measures, which would have to be presented and made acceptable to their voters at home.

The presentation of joint transnational lists would require party groupings to come up with transnational programs acceptable to the party members at home of all kinds of issues that their voters may care for, including taxation, climate change, social welfare, and economic development of less developed countries and regions. In this way they would overcome, by political means, the constitutional limitations on political discourse in the EU.

Moreover, the transnational programs would have to incorporate answers to difficult questions beyond the traditional political cleavages (right vs.left): They would have to include more specific EU cleavages-be it small states vs. big states, south vs. north, or west vs. east-in a way that would be defensible to the constituencies of all participating parties. While we may see in consequence some fragmentation of the political landscape at the far right of the political spectrum, ultimately, any party groupings to the "left" of the extreme right would have to come up with some more EU-community-regarding political programs for Europe as a whole and defend those to their national constituencies - unless they want to relegate themselves to political oblivion.

To conclude, Hayek favored interstate federalism ${ }^{16}$ insofar he believed that such a federation would create grounds for successful economic integration, while at the same time weaken the

\footnotetext{
${ }^{15} I d$.

${ }^{16}$ F.A. Hayek, The Economic Conditions of Interstate Federalism, Found. for Econ. Educ. (Apr. 17, 2017), https://fee.org/ articles/the-economic-conditions-of-interstate-federalism/.
} 
possibility for political intervention and redistribution. He believed that in these enlarged geo-economic spaces, there would be no basis for anything akin to solidarity.

Yet this was to neglect the integrative power of political institutions: The ones that have also created the basis for solidarity at the national level. Over and above, given the aforementioned constraints emerging from the need to present joint EU political programs to various national audiences, transnational lists would facilitate the political organization of those groupings that have more solidarity and European leanings inflected in their political aspirations, thus turning the Hayekian formula on its head. What better way to weaken right-wing populist movements, while at the same time making it easier for EU institutions to act on climate, taxation, redistribution, and migration? 